\title{
Seleksi Penerima Bantuan Pangan Non Tunai di Desa Menggunakan Metode Naive Bayes dan Simple Additive Weighting
}

\author{
Nurul Huda ${ }^{1)}$; Muhammad Hasbi ${ }^{2)}$; Teguh Susyanto ${ }^{3 *}$ \\ ${ }^{1,2)}$ Program Studi Informatika, STMIK Sinar Nusantara Surakarta \\ ${ }^{3)}$ Program Studi Sistem Informasi, STMIK Sinar Nusantara Surakarta \\ 1)16500024.nurul@sinus.ac.id; ${ }^{2)}$ mhasbi@sinus.ac.id; ${ }^{3)}$ teguh@sinus.ac.id
}

\begin{abstract}
Poverty is one of the problems experienced by some developing countries, including Indonesia. There are many ways to mitigate poverty, for example, Indonesian government policy overcome this situation by Non-Cash Food Aid Program (BPNT). The electoral candidate for BPNT in the rural area is carried out by Poverty Reduction Team (SATGASKIN). To avoid uneven and untargeted assistance with the process, a system is capable for addressing the matter. The selection methods in this research were Naive Bayes and Simple additive weighting. The purpose of this research was to design and build an application that provided convenience to SATGASKIN in determining the eligibility of prospective beneficiaries and prioritizing beneficiaries. As a result of the study, the system can be used by SATGASKIN to help determining the recipients' eligibility with $85 \%$ accuracy value, $85.71 \%$ Precision, and $92.31 \%$ Recall. Naive Bayes and Simple Additive Weighting (SAW) methods reached $100 \%$ according to the results by manual calculations.
\end{abstract}

Keywords: Naive Bayes, Simple Additive Weighting, Non-Cash Food Aid

\section{PENDAHULUAN}

Bantuan Pangan Non Tunai (BPNT) adalah bantuan sosial pangan dalam bentuk non tunai dari pemerintah yang diberikan kepada Keluarga Penerima Manfaat (KPM) setiap bulannya melalui mekanisme akun elektronik yang digunakan hanya untuk membeli bahan pangan di pedagang bahan pangan di e-warong. Bahan pangan dalam program bantuan pangan non tunai adalah beras dan/atau telur. Ketentuan mengenai komoditas lainnya ditentukan lebih lanjut berdasarkan kebijakan pemerintah.

Penerima Manfaat BPNT adalah keluarga dengan kondisi sosial ekonomi terendah di daerah pelaksanaan, selanjutnya disebut Keluarga Penerima Manfaat (KPM) BPNT, yang namanya termasuk di dalam Daftar Penerima Manfaat(DPM) BPNT dan ditetapkan oleh Kementerian Sosial (Pedoman Umum Bantuan Pangan Nontunai 2019, 2019).

Salah satu kesulitan yang terkadang dihadapi oleh pemerintah dalam penyaluran BPNT adalah proses pembagian bantuan sosial yang tidak merata dan tidak tepat sasaran. Munculnya masalah tersebut diakibatkan kurangnya pertimbangan atau kemantapan analisis penerima manfaat BPNT dalam menentukan kelayakan pada saat mengajukan pendataan.

Solusi untuk mengatasi permasalahan penyaluran BPNT pernah diusulkan (Arianto et al., 2020), dibangun sebuah aplikasi untuk memilih calon penerima BPNT dengan menerapkan algoritma Analytical Hierarchy Process (AHP) dan Simple Additive Weighting (SAW). Adapun hasil penelitian tersebut belum memberikan hasil yang kurang optimal dalam pemeringkatan calon penerima BPNT dan hasil pembandingan dengan sistem sebelum masih memiliki gap yang tinggi.

Tujuan dari penelitian ini adalah merancang, membangun dan menerapkan Aplikasi Klasifikasi Penerima Bantuan Pangan Non Tunai Di Desa Menggunakan Metode Naive Bayes dan Simple Additive Weighting (SAW).

\section{TINJAUAN PUSTAKA}

Penelitian terkait sebagai sumber rujukan dalam penelitian ini meliputi hasil penelitian (Annur, 2018), (Saleh, 2015), (Lestari \& Kristiyana, 2013), (Arianto et al., 2020) dan 
(Nasution et al., 2019). Hasil penelitian (Annur, 2018) berupa aplikasi untuk mengklasifikasikan masyarakat miskin dengan memanfaatkan algoritma Naive Bayes. Selain itu, juga telah dihasilkan sebuah aplikasi untuk memprediksi besar penggunaan listrik untuk rumah tangga dengan menerapkan algoritma Naive Bayes (Saleh, 2015). Usulan (Lestari \& Kristiyana, 2013) telah menggunakan algoritma Simple Additive Weighting untuk membangun aplikasi sistem pendukung keputusan penentuan keluarga miskin untuk membantu Tim Penanggulangan Kemiskinan (UPT TPK) desa Tamanmartani. Hasil penelitian (Arianto et al., 2020) telah diusulkan aplikasi sistem pendukung keputusan penerima Bantuan Pangan Non Tunai (BPNT) yang menerapkan kombinasi algoritma Analitical Hierarchy Process (AHP) dengan Simple Additive Weighting (SAW). Selain itu (Nasution et al., 2019) juga telah mengusulkan sebuah aplikasi yang memberikan kemudahan kepada pengguna (ahli gizi) dalam mengatur menu makanan diet penyandang diabetes mellitus guna memperoleh status gizi seimbang menggunakan kombinasi metode Naive Bayes dengan Simple Additive Weighting (SAW).

\section{METODE PENELITIAN}

Metode penelitian yang digunakan dalam pembuatan sistem klasifikasi penerima bantuan pangan non tunai di desa menggunakan kombinasi algoritma Naive Bayes dan Simple Additive Weighting terdiri dari beberapa tahapan. Tahapan pengembangan perangkat lunak meliputi:

(1) Pengumpulan data

Data primer penelitian ini yaitu kriteria penerima BPNT meliputi jumlah tanggungan, pendapatan, kepemilikan rumah, material lantai, material dinding, luas bangunan, aset, jenis, transportasi. Data sekunder penelitian ini adalah media pustaka tentang teori teori sistem aplikasi dan metode yang digunakan dalam pembuatan aplikasi, yaitu metode Naive Bayes dan Simple Additive Weighting.

(2) Melakukan analisis sistem, meliputi:

a. Analisis sistem yang berjalan

b. Menentukan skala dari data yang diperoleh

c. Memilih data training

d. Menghitung nilai probabilitas dengan Naive Bayes

Fase penyelesaian dimulai dari Training dan diakhiri dengan proses Testing sehingga dihasilkan sebuah keputusan yang akurat (Nofriansyah \& Nurcahyo, 2019). Berikut ini adalah rumus untuk mencari nilai peluang dari hipotesa benar (valid) untuk data sampel $X$ yaitu:

$$
P(H \mid X)=\frac{P(X \mid H) P(H)}{P(X)}
$$

$X$ merupakan sampel data yang memiliki kelas (label) yang tidak diketahui. $P(H)$ adalah hipotesa bahwa $\mathrm{x}$ adalah data kelas (label). $H$ adalah peluang dari hipotesa H. $P(X)$ merupakan peluang dari data sampel yang di amati dan $P(X \mid H)$ adalah peluang dari data sampel $X$ bila diasumsikan bahwa hipotesa benar. Adapun algoritma penyelesaian dari Naive Bayesian Clasifier seperti berikut:

i. Menghitung nilai peluang kasus baru dari setiap hipotesis dengan kelas (label yang ada) " $P(X K \mid C i)$ "

ii. Menghitung nilai akumulasi peluang dari setiap kelas " $P(X \mid C i)$ "

iii. Menghitung nilai $P(X \mid C i) * P(C i)$

iv. Menentukan kelas dari kasus baru tersebut

e. Pemeringkatan data probabilitas dengan SAW

SAW adalah menentukan nilai bobot untuk setiap atribut, kemudian dilanjutkan dengan proses perankingan yang akan menyeleksi alternatif yang sudah 
diberikan. Adapun algoritma penyelesaian dari SAW (Kusumadewi et al., 2006), seperti berikut:

i. Menentukan alternatif, yaitu $A_{i}$

ii. Menentukan kriteria-kriteria yang akan dijadikan acuan dalam pengambilan keputusan, yaitu $C_{i}$.

iii. Menentukan rating kecocokan setiap alternatif pada setiap kriteria.

iv. Menentukan bobot preferensi tingkat atau kepentingan $(W)$ setiap kriteria $W=\left[\begin{array}{llll}W & W & \text { W3 } & \text { W4 }\end{array}\right]$

v. Membuat matrik keputusan yang dibentuk dari tabel rating kecocokan dari setiap alternatif pada setiap kriteria nilai setiap alternative $\left(A_{i}\right)$ pada setiap kriteria $\left(C_{j}\right)$ yang sudah ditentukan, dimana $i=1,2 m$ dan $j=1,2, . . n$.

$$
X=\left[\begin{array}{ccc}
r_{11} & \cdots & r_{1 j} \\
\vdots & \ddots & \vdots \\
r_{i 1} & \cdots & r_{i j}
\end{array}\right]
$$

vi. Melakukan normalisasi matrik keputusan dengan cara menghitung nilai rating kinerja ternormalisasi $\left(r_{i j}\right)$ dari alternative $A_{i}$ pada kriteria $C_{j}$. Formula untuk melakukan normalisasi tersebut adalah: Penghitungan normalisasi berdasarkan persamaan cost atau benefit.

$$
r_{i j}=\left\{\begin{array}{l}
\frac{x_{i j}}{\operatorname{Max}_{i} x_{i j}} \text { Jikaj adalah atribut keuntungan (benefit) } \\
\frac{\operatorname{Min}_{i} x_{i j}}{x_{i j}} \text { Jikaj adalah atribut biaya }(\text { cost })
\end{array}\right.
$$

Dimana $V_{i}$ merupakan rangking untuk setiap alternatif, $R_{i j}$ adalah rating kinerja ternormalisasi. $M_{a x} x_{i j}$ adalah nilai maksimum dari setiap baris dan kolom, dan $\operatorname{Min}_{i j}$ merupakan nilai minimum dari setiap baris dan kolom.

Nilai $V_{i}$ yang lebih besar mengindikasikan bahwa akternatif $A_{i}$ lebih terpilih adalah:

a) Dikatakan kriteria keuntungan apabila nilai memberikan keuntungan bagi pengambil keputusan, sebaliknya kriteria biaya apabila menimbulkan biaya bagi pengambil keputusan.

b) Apabila berupa kriteria keuntungan maka nilai dibagi dengan nilai dari setiap kolom, sedangkan untuk kriteria biaya dari setiap kolom dibagi dengan nilai.

vii. Hasil dari nilai rating kerja ternormalisasi $\left(r_{i j}\right)$ membentuk matrik ternormalisasi $(R)$.

$$
R=\left[\begin{array}{ccc}
r_{11} & \cdots & r_{1 j} \\
\vdots & \ddots & \vdots \\
r_{i 1} & \cdots & r_{i j}
\end{array}\right]
$$

viii. Hasil akhir dari preferensi $\left(V_{i}\right)$ diperoleh dari penjumlahan dari perkalian elemen baris matrik ternormalisasi $(R)$ dengan bobot preferensi $(W)$ yang bersesuai elemen kolom matrik $(W)$. Nilai preferensi untuk setiap alternatif $\left(V_{i}\right)$ diberikan sebagai :

$$
V_{i}=\sum_{j=1}^{n} w_{j} r_{i j}
$$

Dimana $V_{i}$ merupakan nilai akhir dari alternatif, $W_{j}$ adalah bobot yang telah ditentukan dan $R_{i j}$ merupakan normalisasi matriks. 
(3) Desain Sistem

Perancangan sistem yang digunakan UML meliputi Use Case Diagram, Class Diagram, Sequence Diagram dan Activity Diagram.

(4) Implementasi Sistem

Implementasi sistem digunakan perangkat berbasis web dengan bahasa pemrograman PHP, sedangkan basis datanya menggunakan MySQL.

(5) Pengujian

Pengujian dilakukan dengan membandingkan antara hasil keluaran aplikasi yang dibangun dengan hasil pendataan manual, kemudian untuk mengetahui performa dari aplikasi hasil perbandingan dihitung menggunakan confusion matrix.

\section{HASIL DAN PEMBAHASAN}

Berdasarkan hasil wawancara dengan Petugas kemiskinan terdapat 14 kriteria yang menentukan seorang kepala keluarga berhak atau tidak menerima bantuan pangan non tunai sesuai dengan Keputusan Menteri Sosial Republik Indonesia Nomor : 146 / HUK / 2013 tentang Penetapan Kriteria dan Pendataan Fakir Miskin dan Orang Tidak Mampu (Pedoman Umum Bantuan Pangan Nontunai 2019, 2019). Namun setelah dianalisa lebih lanjut dalam proses penyeleksian dari 14 kriteria tidak semuanya dipakai, dikarenakan mayoritas warga sudah memenuhi kelayakan dari kriteria tersebut Oleh sebab itu dalam penelitian ini mengusulkan 8 kriteria untuk klasifikasi penerima bantuan di desa yaitu jumlah tanggungan, pendapatan dalam satu bulan, status kepemilikan rumah, material lantai, material dinding, luas bangunan, aset, jenis transportasi.

\subsection{Pemilihan kriteria dan skala data penerima}

Berdasarkan hasil pengumpulan dan analisa sistem yang berjalan ditentukan kriteriakriteria, skala nilai kriteria dan bobot kriteria untuk menyeleksi calon penerima BPNT, seperti ditunjukkan pada Tabel 1.

Tabel 1. Penentuan data kriteria, skala dan bobot

\begin{tabular}{|c|c|c|c|}
\hline Kriteria & Himpunan & Nilai & Bobot $(W)$ \\
\hline \multirow{4}{*}{ Jumlah tanggungan (C1) } & $>6$ Orang & 4 & \multirow{4}{*}{$5 \%$} \\
\hline & 5 Orang & 3 & \\
\hline & 4 Orang & 2 & \\
\hline & $<3$ Orang & 1 & \\
\hline \multirow{4}{*}{ Pendapatan (C2) } & $<400$ ribu & 4 & \multirow{4}{*}{$15 \%$} \\
\hline & 400-700 ribu & 3 & \\
\hline & $700-1$ juta & 2 & \\
\hline & $>1$ juta & 1 & \\
\hline \multirow{4}{*}{ Status kepemilikan rumah (C3) } & Magersari & 4 & \multirow{4}{*}{$20 \%$} \\
\hline & Sewa $<1$ juta & 3 & \\
\hline & Milik orang tua & 2 & \\
\hline & Milik sendiri & 1 & \\
\hline \multirow{4}{*}{ Material lantai (C4) } & Tanah & 4 & \multirow{4}{*}{$10 \%$} \\
\hline & Lantai cor & 3 & \\
\hline & Tegel & 2 & \\
\hline & Keramik & 1 & \\
\hline \multirow{4}{*}{ Material dinding (C5) } & Bambu & 4 & \multirow{4}{*}{$10 \%$} \\
\hline & Papan kayu biasa & 3 & \\
\hline & Tembok biasa & 2 & \\
\hline & Tembok kualitas baik & 1 & \\
\hline \multirow{4}{*}{ Luas bangunan (C6) } & $<50 \mathrm{~m} 2$ & 4 & \multirow{4}{*}{$15 \%$} \\
\hline & $50-75 \mathrm{~m} 2$ & 3 & \\
\hline & $75-100 \mathrm{~m} 2$ & 2 & \\
\hline & $>100 \mathrm{~m} 2$ & 1 & \\
\hline
\end{tabular}




\begin{tabular}{|c|c|c|c|}
\hline Kriteria & Himpunan & Nilai & Bobot (W) \\
\hline \multirow{4}{*}{ Aset (C7) } & $<1$ juta & 4 & \multirow{4}{*}{$5 \%$} \\
\hline & $1-5$ juta & 3 & \\
\hline & 5-10 juta & 2 & \\
\hline & $>10$ juta & 1 & \\
\hline \multirow{4}{*}{ Jenis transportasi $(\mathrm{C} 8)$} & Sepeda motor sederhana & 4 & \multirow{4}{*}{$20 \%$} \\
\hline & Sepeda motor 1 & 3 & \\
\hline & Sepeda motor > 1 & 2 & \\
\hline & Mobil & 1 & \\
\hline
\end{tabular}

\subsection{Penentuan kelayakan penerima bantuan dengan algoritma Naive Bayes}

Tahap awal yang dilakukan perhitungan dengan algoritma Naive Bayes untuk menentukan warga yang berhak mendapatkan bantuan. Untuk menunjukkan proses penentuan ini digunakan data training, data sampel yang telah diperoleh dari petugas yaitu 80 orang terdiri dari 50 orang layak dan 30 orang tidak layak. Data training yang akan digunakan disajikan pada Tabel 2.

Tabel 2. Data Training

\begin{tabular}{|c|c|c|c|c|c|c|c|c|c|}
\hline Responden & C1 & C2 & C3 & C4 & C5 & C6 & C7 & C8 & Layak/Tidak \\
\hline 1 & 2 & 3 & 1 & 4 & 3 & 4 & 4 & 4 & 0 \\
\hline 2 & 1 & 3 & 1 & 4 & 3 & 3 & 4 & 4 & 0 \\
\hline 3 & 1 & 3 & 1 & 4 & 3 & 3 & 4 & 4 & 0 \\
\hline 4 & 1 & 3 & 2 & 3 & 3 & 3 & 4 & 4 & 0 \\
\hline 5 & 2 & 3 & 1 & 1 & 3 & 3 & 4 & 4 & 0 \\
\hline 6 & 3 & 3 & 2 & 3 & 3 & 3 & 4 & 4 & 0 \\
\hline 7 & 2 & 2 & 1 & 3 & 3 & 3 & 3 & 4 & 0 \\
\hline 8 & 4 & 3 & 2 & 3 & 3 & 3 & 3 & 3 & 0 \\
\hline 9 & 2 & 3 & 4 & 1 & 3 & 3 & 4 & 4 & 0 \\
\hline 10 & 1 & 4 & 4 & 3 & 3 & 3 & 4 & 4 & 0 \\
\hline 11 & 3 & 2 & 2 & 1 & 3 & 4 & 4 & 3 & 0 \\
\hline 12 & 4 & 2 & 1 & 1 & 3 & 4 & 4 & 3 & 0 \\
\hline 13 & 1 & 2 & 1 & 4 & 3 & 4 & 3 & 3 & 0 \\
\hline 14 & 1 & 2 & 1 & 1 & 3 & 3 & 4 & 4 & 0 \\
\hline 80 & 4 & 1 & 1 & 3 & 1 & 2 & 2 & 1 & 1 \\
\hline
\end{tabular}

Untuk data uji / data testing ditampilkan pada tabel 3.

Tabel 3. Data testing

\begin{tabular}{|c|c|c|c|c|c|c|c|c|}
\hline Responden & C1 & C2 & C3 & C4 & C5 & C6 & C7 & C8 \\
\hline 81 & 2 & 2 & 4 & 2 & 2 & 3 & 4 & 3 \\
\hline 82 & 2 & 2 & 1 & 3 & 2 & 3 & 3 & 2 \\
\hline 83 & 1 & 2 & 2 & 2 & 2 & 3 & 3 & 3 \\
\hline 84 & 4 & 2 & 2 & 3 & 2 & 3 & 3 & 2 \\
\hline
\end{tabular}

Berdasarkan data testing pada Tabel 3, akan ditentukan nilai probabilitas setiap calon penerima dengan menggunakan persamaan (1). Hasil perhitungan dengan Naive Bayes akan masing-masing nilai probabilitas dari kelas ( $P \mid$ Layak) dan $(P \mid$ Tidak layak), sehingga probabilitas tertinggi dijadikan sebagai penentunya. Dari contoh data yang disajikan di atas pada Tabel 4 ditunjukkan contoh hasil perhitungan nilai probabilitas layak dan tidak layak.

Tabel 4. Hasil data testing

\begin{tabular}{|c|c|c|}
\hline \multirow{2}{*}{ Responden } & \multicolumn{2}{|c|}{ Hasil } \\
\cline { 2 - 3 } & Layak & Tidak Layak \\
\hline 81 & $90.59 \%$ & $9.41 \%$ \\
\hline 82 & $32.16 \%$ & $67.84 \%$ \\
\hline 83 & $94.50 \%$ & $5.50 \%$ \\
\hline 84 & $75.49 \%$ & $24.51 \%$ \\
\hline
\end{tabular}




\subsection{Pemeringkatan dengan metode SAW}

Berdasarkan hasil klasifikasi Naive Bayes data yang layak akan diprioritaskan dengan merangking data calon penerima, untuk memberikan nilai prioritas penerima digunakan nilai bobot setiap kriteria seperti pada Tabel 1. Contoh perhitungan hasil pembobotan dengan algoritma SAW ditunjukkan pada Tabel 5.

Tabel 5. Data klasifikasi layak (Naive Bayes)

\begin{tabular}{|c|c|c|c|c|c|c|c|c|}
\hline $\mathbf{R}$ & $\mathbf{C 1}$ & $\mathbf{C 2}$ & $\mathbf{C 3}$ & $\mathbf{C 4}$ & $\mathbf{C 5}$ & $\mathbf{C 6}$ & $\mathbf{C 7}$ & $\mathbf{C 8}$ \\
\hline 81 & 2 & 2 & 4 & 2 & 2 & 3 & 4 & 3 \\
\hline 83 & 1 & 2 & 2 & 2 & 2 & 3 & 3 & 3 \\
\hline 84 & 4 & 2 & 2 & 3 & 2 & 3 & 3 & 2 \\
\hline
\end{tabular}

a. Membuat matriks keputusan X dari Tabel 5.

$$
X=\left[\begin{array}{llllllll}
2 & 2 & 4 & 2 & 2 & 3 & 4 & 3 \\
1 & 2 & 2 & 2 & 2 & 3 & 3 & 3 \\
4 & 2 & 2 & 3 & 2 & 3 & 3 & 2
\end{array}\right]
$$

b. Selanjutnya membuat normalisasi matriks keputusan $\mathrm{R}$ dengan cara menghitung nilai rating kinerja ternormalisasi $\left(r_{i j}\right)$ dari alternatif $\left(A_{i}\right)$ pada kriteria $\left(C_{j}\right)$. Karena atribut kriteria dalam kasus adalah benefit, maka digunakan persamaan (3):

$$
\begin{aligned}
& r_{11}=\frac{2}{\operatorname{Max}(2: 1: 4)}=\frac{2}{4}=0.5 \\
& r_{12}=\frac{2}{\operatorname{Max}(2: 2: 2)}=\frac{2}{2}=1
\end{aligned}
$$

sehingga, diperoleh matriks ternormalisasi $R$ :

$R=\left[\begin{array}{cccccccc}0.5 & 1 & 1 & 0.67 & 1 & 1 & 1 & 1 \\ 0.25 & 1 & 0.5 & 0.67 & 1 & 1 & 0.75 & 1 \\ 1 & 1 & 0.5 & 1 & 1 & 1 & 0.75 & 0.67\end{array}\right]$

c. Tahap selanjutnya adalah mencari nilai dari setiap alternatif, dimana nilai dari setiap kriteria (matriks ternormalisasi $R$ ) akan dikalikan dengan bobot kriteria $(W)$ dan dijumlahkan semua kriterianya. seperti persamaan (5).

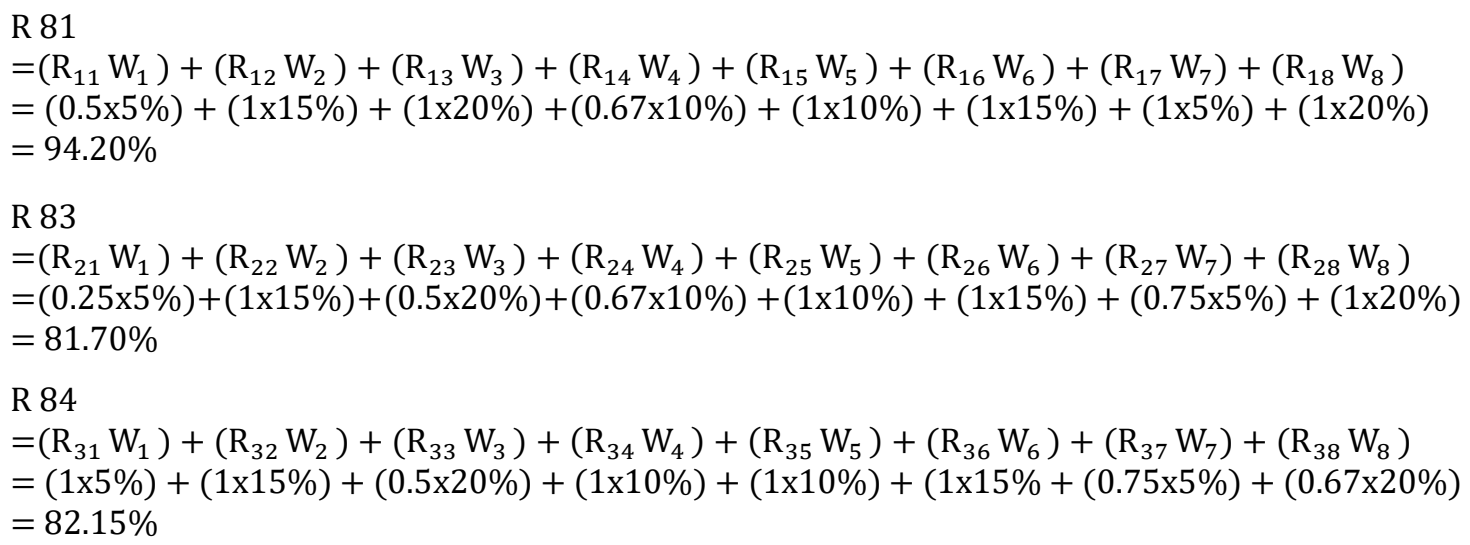

Dengan ini warga 81 mendapatkan peringkat pertama, warga 84 peringkat kedua dan warga 83 mendapatkan peringkat 3 . 


\subsection{Perancangan dan implementasi sistem}

Pada tahap perancangan sistem ini menjelaskan tentang model dari program yang dibangun menggunakan Unified Modeling Language (UML). Pada Gambar 1, diilustrasikan rancangan diagram use case aplikasi penyeleksi penerima bantuan BPNT. Terdapat lima use case utama dalam rancangan ini, meliputi: use case kelola data training, use case kelola data testing, use case kelola data kriteria, use case klasifikasi penerima bantuan BPNT, dan use case perangkingan calon penerima bantuan.

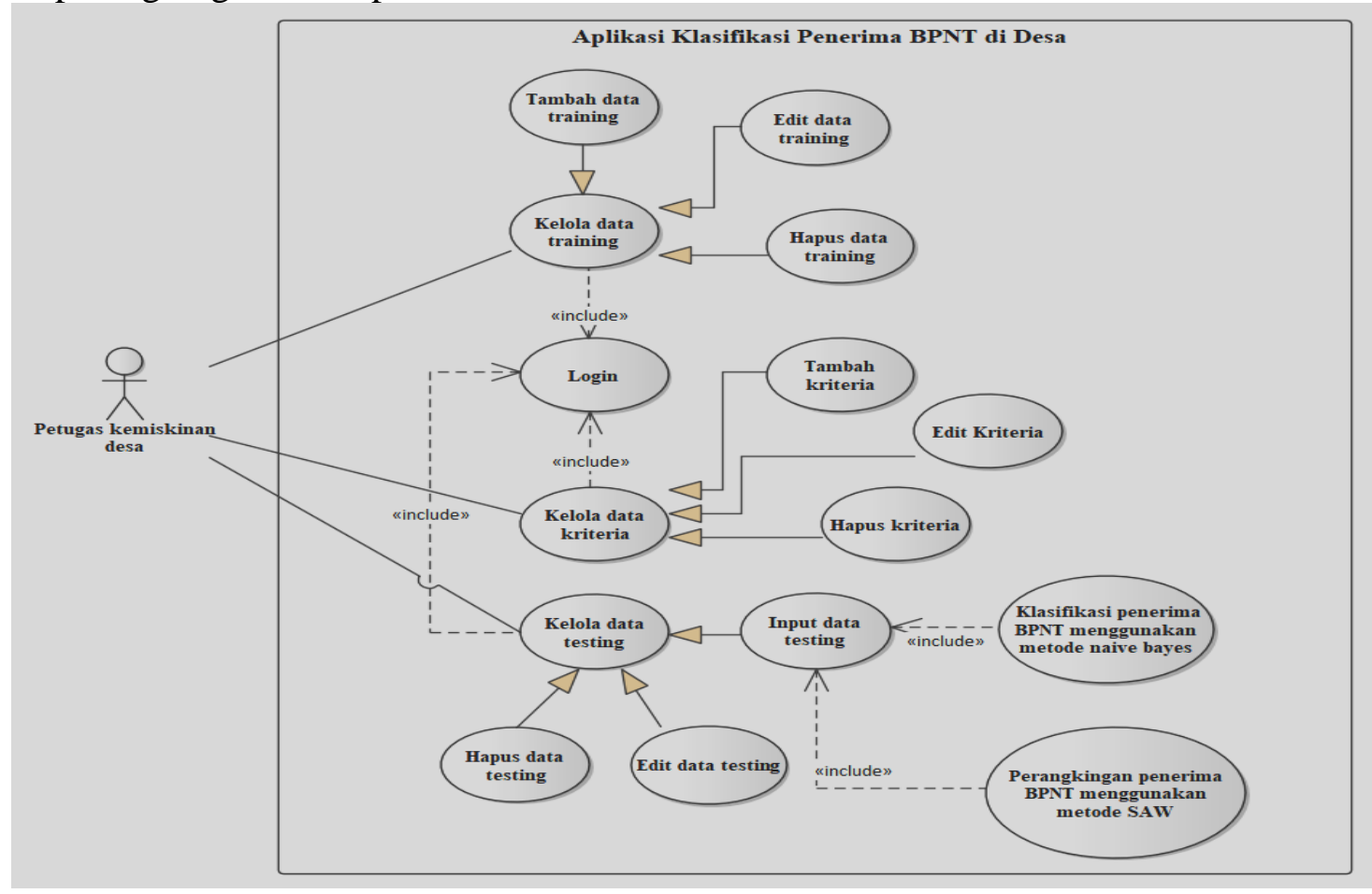

Gambar 1. Use Case Diagram Sistem

Hasil implementasi aplikasi berdasarkan perancangan sistem meliputi:

1. Kelola data training

Pada halaman ini terdapat pilihan tambah data, edit data dan hapus data. Data training yang digunakan adalah data penerima bantuan tahun 2018.

2. Kelola data kriteria

Halaman data kriteria terdapat menu tambah, edit dan hapus data.

3. Kelola data testing

Halaman data testing menampilkan hasil klasifikasi metode Naive Bayes sekaligus untuk menginput data klasifikasi. Halaman ini terdapat menu edit, hapus serta menu rangking yang digunakan untuk perangkingan hasil klasifikasi layak dengan metode SAW.

4. Penentuan perima BPNT

Pada halaman ini menampilkan perhitungan metode Naive Bayes.

5. Perangkingan

Halaman rangking menampilkan perangkingkan dari hasil klasifikasi layak menggunakan metode SAW.

\subsection{Pengujian}

Pengujian Validitas digunakan untuk membandingkan antara hasil dari program yang dibuat dengan hasil pendataan manual dan mengetahui performa dari aplikasi klasifikasi bantuan pangan non tunai di desa menggunakan metode Naive Bayes dan SAW. 
Data yang disiapkan untuk pengujian metode Naive Bayes berjumlah 20 data uji. Proses uji ini dilakukan di tiap tahap proses perhitungan sehingga akan terlihat bahwa program yang dibuat sesuai dengan algoritma yang digunakan. Hasil pengujian dapat dilihat pada Tabel 6 .

Tabel 6. Hasil Pengujian

\begin{tabular}{|c|c|c|c|}
\hline $\begin{array}{l}\text { Data } \\
\text { ke- }\end{array}$ & $\begin{array}{c}\text { Keputusan } \\
\text { (konvensional) }\end{array}$ & $\begin{array}{c}\text { Keputusan } \\
\text { (aplikasi) }\end{array}$ & Keterangan \\
\hline 1 & Layak & Layak & $\mathrm{B}$ \\
\hline 2 & Layak & Layak & $\mathrm{B}$ \\
\hline 3 & Layak & Layak & B \\
\hline 4 & Layak & Layak & $\mathrm{B}$ \\
\hline 5 & Layak & Layak & $\mathrm{B}$ \\
\hline 6 & Layak & Layak & $\mathrm{B}$ \\
\hline 7 & Layak & Tidak layak & $\mathrm{S}$ \\
\hline 8 & Layak & Layak & $\mathrm{B}$ \\
\hline 9 & Layak & Layak & $\mathrm{B}$ \\
\hline 10 & Layak & Layak & $\mathrm{B}$ \\
\hline 11 & Layak & Layak & $\mathrm{B}$ \\
\hline 12 & Layak & Layak & $\mathrm{B}$ \\
\hline 13 & Layak & Layak & $\mathrm{B}$ \\
\hline 14 & Tidak Layak & Layak & $S$ \\
\hline 15 & Tidak Layak & Layak & $\mathrm{S}$ \\
\hline 16 & Tidak Layak & Tidak Layak & $\mathrm{B}$ \\
\hline 17 & Tidak Layak & Tidak Layak & $\mathrm{B}$ \\
\hline 18 & Tidak Layak & Tidak Layak & $\mathrm{B}$ \\
\hline 19 & Tidak Layak & Tidak Layak & $\mathrm{B}$ \\
\hline 20 & Tidak Layak & Tidak Layak & $\mathrm{B}$ \\
\hline
\end{tabular}

Untuk menguji coba sistem yang dibangun digunakan himpunan data histori keputusan proses seleksi periode sebelumnya. Pada Tabel 6 digunakan sebanyak 20 keputusan, yang mana data ini digunakan sebagai pembanding antara pengambilan keputusan cara konvensional dengan sistem aplikasi penyeleksi penerima BPNT. Diketahui hasil pembandingan dua cara pengambilan keputusan tersebut ditunjukkan pada Tabel 6, diperoleh 17 kasus yang memiliki keputusan yang sama dan tiga kasus yang berbeda. Hal ini dapat dinyatakan bahwa cara seleksi antara aplikasi yang diusulkan memiliki hasil yang mirip dengan cara konvensional. Sebagian besar hasil pembandingan aplikasi yang diusulkan memiliki output yang sama dengan cara pengambilan keputusan konvensional. Untuk mempertegas hasil pengujian, digunakan confusion matrix untuk mengukur derajat akurasi, precision dan recall, seperti diperlihatkan pada Tabel 7.

Tabel 7. Matrik confusion pengujian data

\begin{tabular}{|c|c|c|c|}
\cline { 3 - 4 } \multicolumn{2}{c|}{} & \multicolumn{2}{c|}{ Kelas Hasil Prediksi } \\
\cline { 3 - 4 } \multicolumn{2}{c|}{} & Positif & Negatif \\
\hline \multirow{2}{*}{ Kelas Asli } & Positif & 12 & 1 \\
\cline { 2 - 4 } & Negatif & 2 & 5 \\
\hline
\end{tabular}

Untuk menghitung akurasi, precision dan recall digunakan persamaan seperti berikut:

$$
\begin{aligned}
& \text { Akurasi }=\frac{T P+T N}{T P+T N+F P+F N} \times 100 \%=\frac{17}{20} \times 100 \%=85 \% \\
& \text { Precision }=\frac{T P}{T P+F P} \times 100 \%=\frac{12}{12+2} \times 100 \%=85.71 \%
\end{aligned}
$$




$$
\text { Recall }=\frac{T P}{T P+F N} \times 100 \%=\frac{12}{12+1} \times 100 \%=92.31 \%
$$

Hasil dari akurasi diatas dapat disimpulkan kinerja sistem dari 20 data testing menggunakan 80 data training tingkat akurasi $85 \%$, precision $85.71 \%$ dan recall $92.31 \%$. Hal ini dapat dinyatakan bahwa sistem aplikasi seleksi penerima bantuan pangan non tunai memberikan keluaran keputusan yang relevan.

\section{PENUTUP}

\subsection{Kesimpulan}

1. Metode Naive Bayes bekerja dengan cara membandingkan nilai terbesar dari jumlah kelasnya, dan yang terbesarlah menjadi hasil akhirnya, dilanjutkan dengan metode SAW (Simple Additive Weighting) yang bekerja dengan cara merangking hasil dari kelayakan penerima BPNT dengan memberi pembobotan di setiap atribut kelayakan. Kedua metode tersebut cukup efisien dalam penentuan klasifikasi penerima BPNT.

2. Pengujian validitas pada metode Naive Bayes menghasilkan Akurasi 85\%, Precision $85.71 \%$ dan Recall $92.31 \%$. Untuk pengujian metode SAW dilakukan dengan membandingkan hasil perhitungan manual dan perhitungan sistem sudah sesuai. Kinerja metode Naive Bayes dan SAW yang diterapkan dalam permasalahan ini dinilai sudah cukup baik.

\subsection{Saran}

1. Diharapkan aplikasi klasifikasi penerima pangan non tunai dengan metode Naive Bayes dan SAW dapat dikembangkan dengan metode dan bahasa pemrograman yang berbeda

2. Untuk menjaga akurasi klasifikasi penerima pangan non tunai, data training dapat ditambahkan dengan data warga yang mengajukan bantuan yang baru.

3. Program aplikasi klasifikasi penerima bantuan pangan non tunai dengan metode Naive Bayes dan SAW dibuat sebagai usulan untuk desa dalam melakukan klasifikasi penerima bantuan, sistem ini masih cukup sederhana karena lebih mengutamakan inti dari proses perhitungan metode Naive Bayes dan SAW.

\section{DAFTAR PUSTAKA}

Annur, H. (2018). Klasifikasi Masyarakat Miskin Menggunakan Metode Naive Bayes. ILKOM Jurnal Ilmiah, 10(2), 160-165. https://doi.org/10.33096/ilkom.v10i2.303.160165

Arianto, S. R., Siswanti, S., \& Saptomo, W. L. Y. (2020). Sistem Pendukung Keputusan Penerima Bantuan Pangan Non Tunai Dengan Metode Hybrid AHP - SAW. Jurnal Transformatika, 17(2), 200. https://doi.org/10.26623/transformatika.v17i2.1733

Kusumadewi, S., Hartati, S., Harjoko, A., \& Wardoyo, R. (2006). Fuzzy Multi-Attribute Decision Making (Fuzzy MADM). Graha Ilmu. https://opac.perpusnas.go.id/DetailOpac.aspx ?id=718512

Lestari, U., \& Kristiyana, S. (2013). Rancang Bangun Mobile Tracking Application Module untuk Pencarian Posisi Benda Bergerak Berbasis Short Massage Service (SMS). Seminar Nasional Teknologi Informasi Dan Komputasi 2013 (SENASTIK 2013), 2013, $30-31$. 
Nasution, S. R., Andreswari, D., \& Wahyu, T. (2019). Implementasi Naïve Bayes Classifier dan Simple Additive Weighting (SAW) untuk Pemilihan Menu Diet Penyakit Diabetes Mellitus. Jurnal Rekursif, 7(1). http://ejournal.unib.ac.id/index.php/rekursif/1

Nofriansyah, D., \& Nurcahyo, G. W. (2019). Algoritma Data Mining Dan Pengujian. Deepublish.

https://books.google.co.id/books/about/Algoritma_Data_Mining_Dan_Pengujian.html ?id=Fn-QDwAAQBAJ\&redir_esc=y

Pedoman Umum Bantuan Pangan Nontunai 2019. (2019). Kementerian Koordinator Bidang Pembangunan Manusia dan Kebudayaan. https://www.kemsos.go.id/uploads/topics/15767284433221.pdf

Saleh, A. (2015). Implementasi Metode Klasifikasi Naïve Bayes Dalam Memprediksi Besarnya Penggunaan Listrik Rumah Tangga. Citec Journal, 2(3), 207-217. https://citec.amikom.ac.id/main/index.php/citec/article/view/49 